Opinion

\section{Blood disorders: Touching of erythrocytes}

\section{Vyshnavi D*}

Pace Institute of Technology and Science, Andhra Pradesh, India

\section{Introduction}

In general, Erythrocytes may referred to as corpuscle (Red Blood Cells). These erythrocytes will play a significant role in our body. It carries the element round the body and produce dioxide back to lungs. It acquire the element from the lungs then move towards the guts wherever the pure blood is then passed round the body. Erythrocytes covers nearly $1 / 2$ your blood. The mature human erythrocytes is small, Circular, and biconcave; it seems dumbbell-shaped at Look. The concave form of the cell permits 02 exchange at a relentless rate over the biggest doable place. The cell is therefore delicate and appears sort of a bell because it passes through very little blood vessels. It closed with a membrane composed of lipids and proteins, lacks a nucleus, and contains haemoglobin-a red iron-rich macromolecule that binds element. If the organic structure having less count of erythrocytes, it should causes to numerous forms of blood disorders. Therefore the treatments additionally might vary looking on the condition of the blood and its severity. Red blood cells square measure created within the bone marrow. Period of time of erythrocytes is one hundred twenty days. Blood disorders may have an effect on the liquid portion of the blood, this is often referred to as plasma. It primarily target red cells in vertebrates, in order that 02 and dioxide square measure changed as gases, is additional economical and represents a very important biological process development.

\section{Blood disorders affecting of erythrocytes}

Many of the folks do not having any plan regarding their erythrocytes/red blood cells unless they need an unwellness that affects these erythrocytes. Issues with erythrocytes are often caused by sicknesses or a scarcity of iron or vitamins in our body. Some diseases of the red blood cells square measure transmitted.

Disorders of the erythrocytes embody many sorts of anemia. this is often a condition during which there square measure too few red blood cells to hold enough atomic number 8 everywhere the body. Those that square measure full of associateemia could have erythrocytes

\author{
More Information \\ *Address for Correspondence: Vyshnavi D, \\ Pace Institute of Technology and Science, \\ Andhra Pradesh, India, \\ Email: vyshu3196@gmail.com \\ Submitted: December 15, 2020 \\ Approved: December 29, 2020 \\ Published: December 30, 2020 \\ How to cite this article: Vyshnavi D. Blood \\ disorders: Touching of erythrocytes. J Hematol \\ Clin Res. 2020; 4: 01-002. \\ DOI: 10.29328/journal.jhcr.1001014 \\ Copyright: @ 2020 Vyshnavi D. This is an open \\ access article distributed under the Creative \\ Commons Attribution License, which permits \\ unrestricted use, distribution, and reproduction \\ in any medium, provided the original work is \\ properly cited \\ D) Check for updates \\ (1) OPEn Access
}

that have an abnormal form or that look traditional, larger than traditional, or smaller than traditional.

Effects of anemia embody fatigue, quick pulse, pale skin, feeling cold, and, in severe cases, failure. Youngsters WHO do not have enough healthy erythrocytes grow and develop a lot of slowly comparison with the opposite youngsters. These symptoms show however necessary erythrocytes square measure to your standard of living.

Common varieties of anemia:

- Iron-deficiency anemia

- Sickle cell anemia

- Normocytic anemia

- Haemolytic anaemia

- Franconia anaemia

Iron-Deficiency Anemia: If our body doesn't have enough iron, body will not be able to build enough erythrocytes. Irondeficiency anemia is that the most typical variety of anemia. Causes of iron deficiency include:

- A diet low in iron

- Sudden blood loss

- Chronic blood loss, like from serious discharge periods

- Inability to soak up enough iron from food, like from weight-loss surgery 
Sickle cell anemia: During this unwellness, the red blood cells square measure formed like [ $\left.{ }^{*} \mathrm{fr} 1\right]$ moons instead of the conventional circles. This modification in form will build the cells "sticky" and unable to flow swimmingly through blood vessels. This causes a blockage in blood flow. This might cause acute or chronic pain. It may also result in infection or organ injury. Edge tool cells die way more quickly than traditional blood cells-in regarding ten to twenty days rather than a hundred and twenty days. This causes a shortage of red blood cells.

Normocyticanemia:With thissortofanemiayourredblood cells square measure a traditional form and size. However you do not have enough of them to fulfil your body's wants. Diseases that cause this sort of anemia square measures usually semi-permanent conditions, like nephropathy, cancer, or rheumatism.

Haemolytic anaemia: This sort of associateemia happens once red blood cells square measure destroyed by an abnormal method in your body before their period of time is over. As a result, your body does not have enough red blood cells to operate. And your bone marrow cannot build enough to stay up with demand.

Franconia anaemia's: This is often a rare hereditary condition during which your bone marrow is not able to build enough of any of the elements of blood, as well as red blood cells. Youngsters born with this disorder usually have serious birth defects owing to the issues with their blood. They will develop malignant neoplastic disease.

\section{Conclusion}

Blood disorders have an effect on one or additional components of the blood and forestall your blood from doing its job. They will be acute or chronic. Several blood disorders area unit hereditary. Alternative causes embody alternative diseases, facet effects of medicines, and a scarcity of bound nutrients in your diet. 